\title{
MRI 環境対応小型手術支援 7 自由度マニピュレータの開発 The development of 7DOF Manipulator Driving Surgical Tools for the Compact Surgical Support System with MR-compatibility
}

\author{
○正 岸 宏亮(日立機械研,早大) 橋爪 誠(九大) \\ 正 藤江 正克(早大) 正 佐久間 一郎(東大) 正 土肥 健純(東大) \\ Kousuke KISHI, Hitachi, Ltd. / Waseda Univ. kosuke.kishi.zt@hitachi.com \\ Makoto HASHIZUME, Kyusyu Univ. \\ Masakatu G FUJIE, Waseda Univ. \\ Ichiro SAKUMA, Univ. of Tokyo. \\ Takeyoshi DOHI, Univ. of Tokyo.
}

\begin{abstract}
The concept and specification of a compact surgical manipulator for intervention support systems in MRI (Magnetic Resonance Imager) was studied with authorities. Based on this specification, the design/prototype production was performed about a compact surgical manipulator, surgical tools, and a control unit. In consideration of spatial interference with the receiving coil or a patient body surface in the gap of opened type MRI, modularization, and number of the necessary degree of freedom, we developed seven-degree-of-freedom compact surgical manipulators driving surgical tools. This manipulator can work in space of $430[\mathrm{~mm}]$ high. In addition, the surgical tool is exchangeable, and has three degree of freedom at the tip that the manipulator can drive without using a wire. We evaluated MR compatibility of the manipulator, and confirmed that no problem occurred in both sensors and a movement range.
\end{abstract}

Key Words : MRI, MR compatibility, Forceps, Tendon wire mechanism, Power transmission mechanism

\section{1. 序論}

できるだけ小さな切開(侵襲)で, 内視鏡と術具を用いて治 療を施す低侵襲手術は, 術者が直接患部を見ることも触る こともできないため，外科医への負担が大きい，そこで， 低侵襲治療の普及をより拡大させ, これを安全かつ確実に 施行するために, 従来術具では困難であった手術操作や動 作範囲，アプローチ方法をマニピュレータの支援により可 能とし, さらに高機能診断機器からの情報を用いることに より限られた視野を補完し, 危険領域への誤ったアクセス を回避するナビゲーションを有するシステムの実現が重要 である.これを実現するために, 高機能診断機器として MRI を用い, その中で動作可能な小型軽量化した手術支援マ二 ピュレータシステムと, 術中の患部およびその周辺の情報 を提供する画像誘導ナビゲーションから成り立つ手術支援 システムを開発する(1).

\section{2. システムコンセプト}

本システムが目指す概念図をFig. 1に示す，診断装置であ る開放型 MRI, 患部を観察する内視鏡, これら複数の画像 情報を統合して提供する情報統合コントローラ, および本 研究で開発中のマスタ・スレーブマニピュレータシステム, マニピュレータシステムと開放型 MRI を物理的に統合する 手術台から構成される MR 画像誘導手術支援ロボティック システムの実現を目指している，本システムを用いる際に は，外科医は術中に，情報統合コントローラによって提供 される術中ナビゲーション画像や内視鏡画像, 術前診断画 像等をもとに，マスタデバイスを用いて多腕の MRI 対応小 型手術支援マニピュレータ(スレーブマニピュレータ)を操 作し, 治療行為を行う.スレーブマニピュレータ先端には, 内視鏡や術具, 穿刺針等を取り付けられるようにする. 対 象とする手術は, 体腔内臟器や器官全般の手術であるが, まずは解剖学的に比較的明確になっている肝臓をターゲッ トとして研究を進める.

本報では，本システムで用いるスレーブマニピュレータ
のうちの一つである術具駆動マニピュレータについて述心゙ る. 術具駆動マニピュレータは，MRI 環境下における穿刺 針治療の際の対象の保持や，作業空間を作るための藏器圧 排といった動作，内視鏡下手術における把持・切開・吻合 といった様々な手技の実現を目的とする.

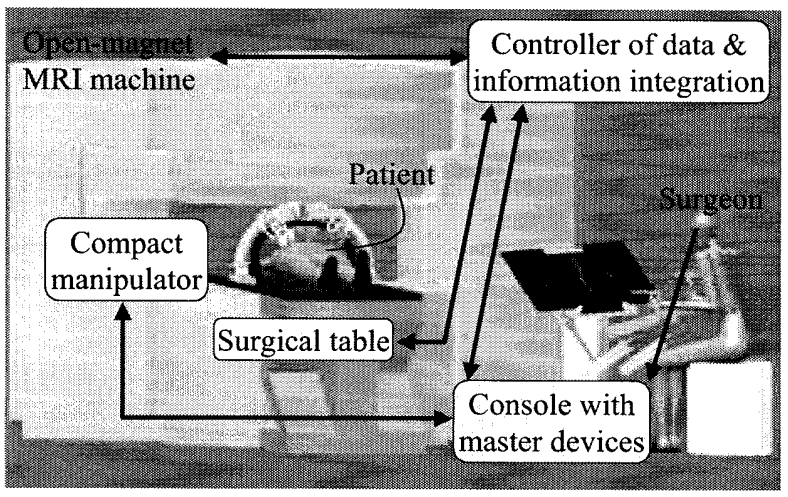

Fig. 1 Conceptual image

$$
\text { 3. 術具駆動マニピュレータ }
$$

\section{1 技術課題}

術具駆動マニピュレータを開発するにあたり問題となる 課題は, (1)高さ $430[\mathrm{~mm}]$ という MRI ガントリの狭隘空閒性, (2)高周波強磁場空閒 $(0.3[\mathrm{~T}])$, (3)医療機器としての安全性確 保といった大きく分けて 3 つの項目が挙げられる. MRI 環 境下に㧍いて体腔内で任意の手技を行うためには，これら の課題を解決し, 術具先端部で位置姿勢の 6 自由度と術具 開閉の 1 自由度を有する必要がある.

MRI の狭险空閒において, 患者やMRIの RFコイル，他 の医療機器などと干渉せずにマニピュレータを設置するた めには，体腔内に挿入される術具以外のマニピュレータ高 さを $15[\mathrm{~cm}]$ 程度に収めなければならないことがわかった。 高さ $15[\mathrm{~cm}]$ 程度の中に, 体腔内で直径 $15[\mathrm{~cm}]$ 程度の円を動 作範囲とするために，マニピュレータとして大きな体積を 占める駆動源をマニピュレータ構造体から分離し, 動力伝 達手段を確立することによりマニピュレータを小型化する.

[No. 06-4] Proceedings of the 2006 JSME Conference on Robotics and Mechatronics, Waseda, Japan, May 26-28, 2006 
駆動源をマニピュレータ本体から分離するということは, 高周波高磁場空間対策にもつながる. 磁場との干渉を防ぐ ために, マニピュレータの駆動源として超音波モータ(新生 工業：USR-60 非磁性タイプ)を用いる. MRI 撮像領域中心 から超音波モータをどれだけ遠ざければMRI画像に影響が ないかを実験的に調べ，約 $50[\mathrm{~cm}]$ 以上遠ざければ問題がな いことを確認した，そこで，本システムは安全率を見込み $70[\mathrm{~cm}]$ 以上遠ざけた位置から 7 自由度を駆動する配置とし た。構造体は, 高周波高磁場環境および滅菌性を考慮し, 撮像中心に近い部分では, PEEK®やチタン合金を用いる. センサとしては, 超音波モータと一体型の電気式エンコー ダにノイズ対策を施したものを使用する.

よって，これらの条件をデザインレベルで考えると， (a) $70[\mathrm{~cm}]$ 以上の動力伝達手段の確立, (b)約 $15[\mathrm{~cm}]$ で 7 自由 度という小型な形状でありながら，磁場環境に影響を与え ない材料で, 医療機器として運用可能な機構の確立, (c)こ れらを制御する超音波モータのサーボ制御技術の確立，と いった技術的課題が浮かびあがる.これらの問題点を解決 した術具駆動マニピュレータについて本報では(a), (b)の観 点を中心に述べる.

\section{2 自由度配置}

内視鏡下手術では術具径に相当する穴(刺入点)を体表に 開け, 術具が刺入点を中心にピボット運動する必要がある. すでに報告済みの術具保持マニピュレータ (2)は, 平行リンク を用いた RCM(Remote Center Motion)機構により 2 自由度の ピボット運動を実現し, 刺入点の位置決めはガイドフレー ムおよびその取り付け具により設定可能となっている。こ れに更なる自由度, 即ち術具の直動, 術具軸の回転, 術具 先端での 2 自由度, 開閉の 1 自由度を追加して 7 自由度の 術具駆動マニピュレータを開発する. 3.1(b)で述べたように， 医療機器として考えると, 術具は術中の状態に応じて様々 な種類のものを交換して利用する必要があるため, マニピ ュレータに対して容易に着脱可能にできる必要がある。そ こで術具自体を直動, 回転させる術具駆動部と, 先端 3 自 由度を有する術具を開発し, 術具駆動部と術具は, 工具を 使うことなく容易に着脱可能な構造とした。

\section{3 制御性を向上させる術具}

開発した術具は, 屈曲 2 自由度, 開閉 1 自由度の先端 3 自由度を, 一切のワイヤを用いず剛体のロッドとリンク, ギアにより駆動を実現する，また，屈曲の 2 自由度は干渉 することなく独立に駆動が可能であり，動作範囲はそれぞ れ土90[deg]となっている.これにより, ワイヤの断裂や, ワイヤたるみによるヒステリシス, 頻繁な術具メンテナン スといった問題が解決し，制御性が向上する.

\section{4 動力伝達手段}

3.1(a)を実現するために，撮像中心から $70[\mathrm{~cm}]$ 以上離れた 位置に配置した超音波モータからタイミングベルトにより 動力を伝達し(この機構を駆動部と呼ぶ), そこからさらに各 関節一蛇管ワイヤ機構を用いて $50[\mathrm{~cm}]$ 程度の距離を動力伝 達することにより実現している．蛇管ワイヤ機構は，マ二 ピュレータを任意の位置に配置可能にするために用いてい る. また, 術具先端 3 自由度へ動力を伝達する機構として, フッ素チューブの中に可撓性を有するエンジニアリングプ ラスチックのロッド(仁礼工業 : PEEK®ロッド)を通し, PEEK®ロッドの両端に, ラックを切った剛体のロッドを取 り付け，駆動力を直動運動として伝達する蛇管ロッド機構
を開発した. 蛇管ロッド機構は, 蛇管ワイヤ方式のように 1 自由度に 2 本の管を必要とすることなく，一本のロッドの 押し引きにより動力を伝達するため空間効率がよい，また， 蛇管ロッド機構では，蛇管ワイヤ方式のようなワイヤの断 裂，緩みといった問題が発生しにくく，メンテナンスの必 要頻度が大幅に低減する，中継ボックスと駆動部は，工具 を使うことなく容易に着脱が可能である.

\section{5 評価}

Fig. 2に術具駆動マニピュレータ及びその駆動系, Fig. 3 に着脱可能なワイヤを用いない 3 自由度術具を示す.

開発した本システムが，MRI が有する高周波高磁場環境 に対して影響を及ぼしていなか，逆にマニピュレータが MRIから影響を受けていないか，また MRIの狭险空間にお いて, マニピュレータが物理的に干渉することなく動作が 可能かどうか, を評価するために, 実際に MRI(日立メディ コ:AIRIS II comfort，静磁場強度 0.3 [T] )内部に配置して駆動 実験を行った. Fig. 2に示すように, MRI 装置との機械的な 干渉もなく, MRI 磁場環境下で動作可能であり，MR 画像 への影響も運用により臨床への影響がないレベルであるこ とを確認した。

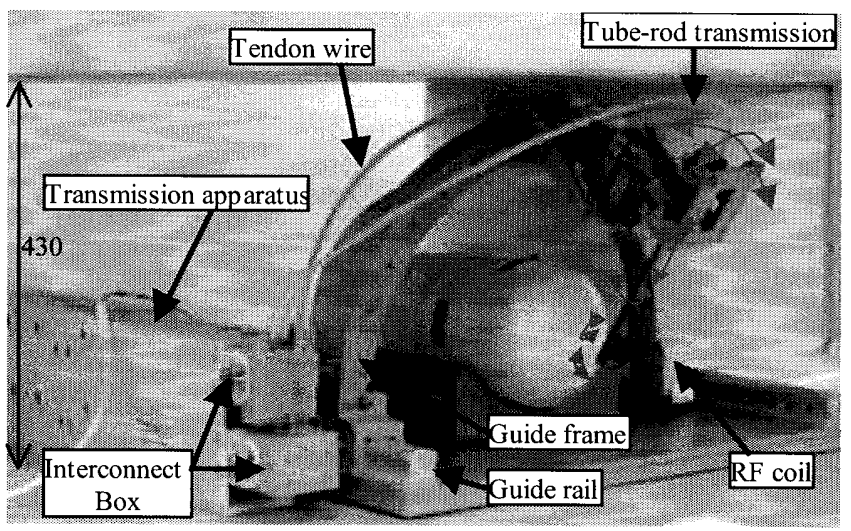

Fig. 2 Manipulator system for driving surgical tools in MRI

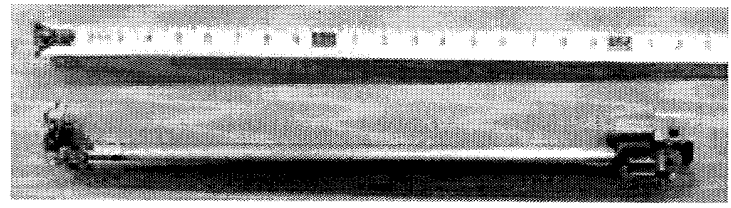

Fig. 3 Interchangeable wireless forceps

\section{4. 結論}

$70[\mathrm{~cm}]$ の距離で動力を伝達する駆動部，ワイヤを用いず に先端で 3 自由度駆動可能な術具, 術具が容易に着脱可能 な術具駆動部を開発することにより，全 7 自由度の術具駆 動マニピュレータを開発した。これを MRI 環境下で用い, 影響を受けずに動作可能であること，逆に MR 画像への影 響が臨床に使えるレベルであることを確認した。

\section{謝辞}

本研究は独立行政法人新エネルギー・産業技術総合開発機構 （NEDO）基盤技術研究促進事業「未来型医療を実現する小型手術 用ロボティックシステムの研究開発」の委託により実施した。

\section{文献}

[1] 岸宏亮他, “MR 画像誘導小型手術支援システムのコンセプ 卜, ” ROBOMEC2005 講演論文集, 2P1-N-122, 2005.

[2] 岸宏亮他, “MR 画像誘導小型手術支援穿刺針保持マニピュレ 一夕の開発,”第 14 回日本コンピュータ外科学会大会論文集, pp.179-180, 2005. 